\title{
Kulturotwórcza rola szkoły wiejskiej na przykładzie działalności Szkoły Powszechnej w Lopiennie w latach 1918-1939 (wybrane problemy)
}

\begin{abstract}
Abstrakt
Po odzyskaniu przez Polskę niepodległości w 1918 r. bardzo ważną kwestią było przekształcenie i ujednolicenie wszystkich szczebli szkolnictwa. Działalność szkół wiejskich w dwudziestoleciu międzywojennym wpływała nie tylko na sferę edukacyjno-wychowawczą, ale także na przejawy aktywności społeczno-kulturowej. Celem artykułu jest ukazanie różnorodności form działalności na rzecz społeczności prowadzonych przez Szkołę Powszechną w Łopiennie: organizowanie obchodów rocznic ważnych wydarzeń historycznych, politycznych i religijnych, organizowanie wieczorowych kursów dokształcających, pogadanek i wykładów, zaangażowanie nauczycieli w działalność równych towarzystw i organizacji lokalnych.
\end{abstract}

Słowa kluczowe: szkolnictwo powszechne w dwudziestoleciu międzywojennym, Szkoła Powszechna w Łopiennie, działalność społeczno-kulturowa wsi.

\section{The Culture-Forming Role of the Rural School with the Example of the Activity of the Elementary School in Łopienno, 1918-1939 (Selected Problems)}

\begin{abstract}
After Poland regained independence in 1918, the transformation and unification of all levels of education became a very important issue. The activity of rural schools in the interwar period influenced not only the educational sphere but also the manifestations of socio-cultural activity. The aim of the article is to show the diversity of
\end{abstract}

\footnotetext{
* Uniwersytet im. Adama Mickiewicza w Poznaniu, Wydział Studiów Edukacyjnych. Artykuł otrzymano: 17.02.2020; akceptacja: 20.03.2020.
} 
forms of activity for the benefit of communities run by the Elementary School in Łopienno: organizing celebrations of anniversaries of important historical, political and religious events, organizing evening, training, courses, talks and lectures, teacher involvement in the activities of various local societies and organizations.

Keywords: elementary/primary education in the interwar period, Elementary School in Łopienno, socio-cultural rural activities.

\section{Wprowadzenie}

We współczesnym świecie, w którym z jednej strony dąży się do indywidualizmu, oryginalności i kreatywności, z drugiej przyjmuje się postawę konformistyczną, cenne wydaje się przygotowanie jednostek do świadomego funkcjonowania w społecznościach lokalnych. Kulturę poznaje się, aktywnie uczestnicząc w życiu „małej ojczyzny”, dopiero z czasem rozszerza się swoją perspektywę na kraj i świat. Ale, aby w tej (K)ulturze uczestniczyć, należy poznać historię regionu, jego specyficzne uwarunkowania geograficzne, społeczne i kulturalne. Badania regionalne będące dziś, jak zauważa Edyta Głowacka-Sobiech (2008), rekonstruując poglądy współczesnych badaczy nauk społecznych, „odpowiedzią na metanarrację (...) lub (...) formą buntu przeciwko globalizacji i wizji świata przedstawionego jako globalna wioska (...) na trwałe wpisały się w problematykę badawczą historii wychowania" (Głowacka-Sobiech 2008: 9).

Według Jerzego Topolskiego badania regionalne wywodzą się „z dziewiętnastowiecznego rozbudzenia świadomości historycznej usiłowania licznych „miłośników” historii, aby ukazywać „starożytności” lokalne, tzn. godne przypomnienia fakty, ludzi czy miejsca (Topolski 1977: 423, za: Głowacka-Sobiech 2008: 8; por. Topolski 1978; Mokrzecki, Żerko 1989).

Odkrycie, opisanie i propagowanie regionalnych treści stanowi współcześnie istotne pole eksploracji badawczej.

Jednym z nich jest podjęcie badań nad szkolnictwem powszechnym w Wielkopolsce w dwudziestoleciu międzywojennym z perspektywy historii wychowania. Problematyka ta doczekała się tylko jednego syntetycznego opracowania Stanisława Michalskiego Szkolnictwo powszechne i zakłady kształcenia nauczycieli $w$ Wielkopolsce w okresie międzywojennym (1962 r.), w którym podjęto kluczowe problemy (m.in. funkcjonowanie szkół byłej dzielnicy pruskiej, programy szkół powszechnych czy też stanowisko głównych ugrupowań społeczno-politycznych regionu poznańskiego wobec szkoły powszechnej). W tych dociekaniach, ze względu na ich uogólniający charakter, nie podjęto analizy materiałów źródłowych ze wszystkich inspektoratów szkolnych. Nie ma w nich egzemplifikacji m.in. funkcjo- 
nowania szkół w obrębie Powiatowego Inspektoratu Szkolnego w Wągrowcu ${ }^{1}$. Ponadto, problematykę szkolnictwa powszechnego na terenach dawnego zaboru pruskiego podjęto w monografiach (Trzebiatowski 1970; Garbowska 1976), a także w pracach rozproszonych (Sieciński 2016; Jamrożek 1989; Jamrożek 1985).

Niniejsze rozważania, do których napisania przyczynkiem stały się obchody 500-lecia nadania praw miejskich Łopiennu², mają na celu zasygnalizować istotność takich badań. Aby móc pokazać syntetycznie rozwój pewnych ponadregionalnych tendencji zarówno w edukacyjno-wychowawczym, jak i pozaszkolnym aspekcie funkcjonowania wiejskiej szkoły powszechnej w latach 1918-1939, trzeba podjąć trud „badań cząstkowych” (Głowacka-Sobiech 2008: 10). Próba rekonstrukcji kulturotwórczej roli Szkoły Powszechnej w Łopiennie w latach 1918-1939, podlegającej Inspektoratowi Szkolnemu w Wągrowcu, ma przede wszystkim pokazać, jak znaczącą rolę społeczno-kulturową pełniła ówczesna szkoła wiejska. Łopieńska placówka, podobnie jak inne na terenie Wielkopolski, kreowała - wraz z różnymi, lokalnymi stowarzyszeniami - życie społeczne mieszkańców wsi. Według Marii Biernackiej „Dobrze funkcjonująca szkoła oddziaływała poprzez upowszechnianie umiejętności czytania i pisania, popularyzację książek, organizowanie różnych imprez kulturalnych i wreszcie przez bezpośrednie oddziaływanie ówczesnych nauczycieli" (Biernacka 1983: 113). Należy pamiętać, że ów ruch kulturalny na wsi z jednej strony inicjowany był oddolnie - przez liderów wiejskich społeczności - przede wszystkim nauczycieli (ale także i księży oraz sołtysów), na co zwracano uwagę już podczas kongresów i zjazdów pedagogicznych w dwudziestoleciu międzywojennym (Jamrożek 2015: 158-167), z drugiej stał się również kwestią regulowaną legislacyjnie. Ustawa z 11 marca 1932 r., inicjująca reformę szkolną, wprowadziła 7-letni obowiązek szkolny dla każdego dziecka, a także kursy dokształcające oraz instytucje oświaty pozaszkolnej dla młodzieży powyżej lat 18 oraz dorosłych, umożliwiające pogłębianie i rozszerzanie wykształcenia (Jamrożek 2015: 163-164). Należy również przywołać fakt, iż w poglądach pedagogicznych pojawiła się, szczególnie wśród ludowców, koncepcja szkoły,

która eksponowała ścisłe związki tej instytucji ze społecznością lokalną, która wyznaczała tej placówce i zatrudnionemu w niej personelowi peda-

\footnotetext{
1 W dokumentach archiwalnych oprócz nazwy Powiatowy Inspektorat Szkolny w Wągrowcu występują także nazwy: Inspektorat Szkolny w Wągrowcu. „W wyniku przekształceń prawnych mających miejsce w 1933 roku Powiatowy Inspektorat Szkolny w Wągrowcu zlikwidowano, a teren jego działania włączony został w kompetencje Obwodowego Inspektoratu Szkolnego w Chodzieży. Rozporządzenie Ministra W.R. i O.P. z dnia 8 lutego 1938 r. w sprawie zmiany rozporządzenia z dnia 14 lipca 1933 roku wprowadziło zmianę w sprawie podziałów na okręgi szkolne. Zgodnie z nowymi przepisami powołano na powrót w Wągrowcu Inspektorat Szkolny Wągrowiecki obejmujący teren powiatu wągrowieckiego. Rozporządzenie weszło w życie dn. 1 kwietnia 1938 r. Taki podział utrzymał się do wybuchu II wojny światowej" (https://szukajwarchiwach.pl/92/338/0/?q=inspektorat+szkolny+ $\mathrm{w} \%$ C4\%85growiec+XARCHro:92\&wynik=9\&rpp=15\&page=1\#tabZespol [dostęp: 25.11.2019]).

2 Szkoła w Łopiennie nie doczekała się monografii, a historia samej miejscowości zawiera wiele luk i również brak jej całościowego studium.
} 
gogicznemu zadania planowej interwencji w pozaszkolne środowisko życia uczniów (na płaszczyźnie wzajemnej współpracy szkoły i nauczyciela z rodzinami uczniów i innymi kręgami oraz instytucjami znajdującymi się w środowisku) (Jamrożek 1989: 39).

Wiele z przedstawionych wyżej przejawów aktywności pozaszkolnej można wskazać w działaniach organizowanych na rzecz społeczności lokalnej, podejmowanych przez nauczycieli szkoły w Łopiennie. Uczniowie, biorąc aktywny udział w uroczystościach lokalnych, poznawali nie tylko historię regionu i kraju (np. obchody rocznicy 3 Maja), ale także reagowali na ważne, aktualne wydarzenia polityczne (np. przejazd prezydenta Mościckiego przez Łopienno) czy też uczestniczyli w wydarzeniach religijnych (np. jasełka). Co ważne, wszystkie obchody różnych uroczystości były organizowane dla mieszkańców Łopienna i okolicy. Nierzadko dla wielu dorosłych był to jedyny sposób poznania historii kraju i regionu, a także jedyna forma uczestnictwa w kulturze. Ponadto, należy zauważyć, że ówcześni wiejscy nauczyciele, będąc niewątpliwie liderami małych społeczności (wraz ks. proboszczem i sołtysem), kreowali życie społeczno-kulturowe wsi, nie tylko przygotowując okolicznościowe akademie, ale także angażując się w działalność towarzystw lokalnych czy też, co warte podkreślenia, organizując wieczorowe kursy, wykłady oraz pogadanki dla rodziców i dorosłej społeczności lokalnej. Cieszyli się poważaniem i zaufaniem społecznym.

Do analizy kulturotwórczej roli Szkoły Powszechnej w Łopiennie w dwudziestoleciu międzywojennym zostały wykorzystane przede wszystkim źródła szkolne. Pomijając niejednoznaczność semantyczną źródeł szkolnych, w niniejszym opracowaniu przyjęto za Urszulą Wróblewską szeroką ich definicję: „źródła szkolne to wszystkie wytwory, dokumenty, pamiątki świadczące o życiu szkolnym i codziennym społeczności lokalnej” (Wróblewska 2017: 43). Jak trafnie zauważa, źródła szkolne

Zachowują w pamięci i przekazują treści dotyczące ważnych przestrzeni życiowych szkoły. Są jednocześnie nośnikiem pamięci zbiorowej, jak i biorą udział w jej kształtowaniu, przebudowie i utrwalaniu. (...) Pełnią rolę medium, za pomocą którego przekazywane są informacje o zmianach zachodzących w obrębie grupy szkolnej i lokalnej (Wróblewska 2017: 48; por. Gołdyn 2019: 116-166).

Wśród analizowanych źródeł szkolnych znalazły się zarówno dokumenty pisane, jak i ikonograficzne. Do pierwszej grupy należy zaliczyć przede wszystkim Kronikę Szkoły z lat 1887-1938 prowadzoną w układzie chronologicznym przez

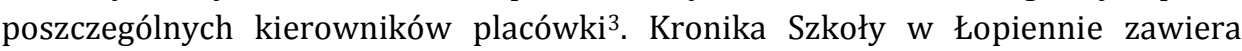

${ }^{3}$ Kronika Szkoły w Łopiennie znajduje się w Archiwum Państwowym w Poznaniu, sygn. 53/875/
0/57/223 (jest to jedyna przedwojenna zachowana kronika szkoły w Łopiennie). W dokumencie tym 
informacje charakterystyczne dla tego typu źródeł: dane statystyczno-informacyjne, życie szkolne, życie uczniowskie, otoczenie społeczne (por. Wróblewska 2017: 49).

Ponadto, w analizie wykorzystano dokumenty archiwalne, szczególnie zespołu Inspektoratu Szkolnego w Wągrowcu, na podstawie których można scharakteryzować prowadzone w szkole wieczorowe kursy dokształcające (m.in. zgłoszenie trwania kursu adresowane przez kierownika szkoły do inspektora, listy obecności, prowadzący zajęcia) oraz wypełnić luki dotyczące historii placówki (np. protokoły zdawczo-odbiorcze przekazania majątku szkół w Łopiennie i Łopiennicy). W tej kwestii wartościowym źródłem są także dokumenty komisji kolonizacyjnej, które posłużyły do próby skreślenia rysu historycznego szkoły. Cennym materiałem źródłowym jest również opracowanie dotyczące historii Łopienna ks. Władysława Stryjakowskiego z roku 1887 Wiadomości o Łopiennie i jego kościele na pamiątkę dwóchsetnej rocznicy konsekracji kościoła.

Wiele ważnych informacji o różnorodnych formach działalności szkoły w Łopiennie można znaleźć w prasie - zarówno lokalnej (np. gnieźnieńska gazeta „Lech”), jak i regionalnej (np. „Wielkopolanin”, „Gazeta Wągrowiecka”) (Kolasa, Jarowiecki 2015; Spaleniak 1994/1995). Korespondenci w prasie umieszczali zarówno drobiazgowe opisy obchodów uroczystości, np. rocznicy uchwalenia Konstytucji 3 Maja („Gazeta Wągrowiecka” 1930a), jak i krótkie informacje o odbytych wydarzeniach, np. wieczorowych kursach dokształcających („Gazeta Wągrowiecka" 1934b). W niniejszych rozważaniach wykorzystano również (nielicznie zachowane, znajdując się w kolekcjach prywatnych) źródła ikonograficzne, szczególnie zdjęcia z uroczystości obchodów 3 Maja oraz pocztówki z widokami infrastruktury szkoły.

\section{Łopienno - położenie geograficzne i uwarunkowania historyczne}

Łopienno to miejscowość geograficznie położona na obszarze Pojezierza Gnieźnieńskiego, na pograniczu Kujaw i Wielkopolski; obecnie w województwie wielkopolskim, powiecie gnieźnieńskim, gminie Mieleszyn, nad rynnowym jeziorem

\footnotetext{
znajdują się opisy życia wewnętrznego szkoły (ilości uczniów w poszczególnych rocznikach, okres trwania ferii i wakacji świątecznych czy też wiadomości o nauczycielach i kierownikach - ich dokształcaniu, uczestnictwie w konferencjach powiatowych itp., warunkach lokalowych), jak i opisy życia zewnętrznego szkoły - przemiany społeczno-polityczne, szczególnie w latach 1919-1923 (m.in. przebieg walk o wschodnie granice kraju, zamach na prezydenta Gabriela Narutowicza) oraz szczegółowe opisy działalności (poza)szkolnej, m.in. przebiegi uroczystości, akademii itp. Obowiązek prowadzenia kronik szkolnych regulowało zarządzenie ministra Adalberta Falka z 15 X 1872, Centralblatt für die gesammte Unterrichts Verwaltung in Prussen, nr 10, z 31 X 1872, s. 588 (Szczepaniak, Tyrchan 2015: 7).
} 
Łopienno Południowe. Jej losy tworzą interesującą kartę historii regionu4. Pierwsze wzmianki o Łopiennie sięgają połowy XIII w. ${ }^{5}$, ważnym momentem jest nadanie praw miejskich przez króla Zygmunta I w roku 1519 (Rocznik Dziejów Społecznych i Gospodarczych 1935: 12, 35, 58, 59; Stryjakowski 1887: 11), a także ustanowienie Łopienna wsią w roku 18886. Właścicielami Łopienna byli: Andrzej Zakrzewski, Jan Latalski, Piotr Czarnkowski (ufundował drewniany kościół), Jan Smoszewski i rodzina Smoczewskich, Władysław Michał Skoroszewski i jego rodzina, Hieronim Zawadzki, Leon Grudzielski, Augustyn Wyszogota Zakrzewski. Od 1823 r. Łopienno dzierżawili: Zdębiński, Rudnicki, Chodoręski. W 1838 r. miejscowość została sprzedana przez fiskus, który nabył dobra łopieńskie, Niemcowi Wirthowi. W 1886 r. wieś Łopienno została kupiona przez Jakóba Lewina (Stryjakowski 1887: 10-13; por. Kościński 1909: 147-148; Słownik geograficzny... 1880-1914). W XIX stuleciu terytorialnie Łopienno należało do regencji bydgoskiej (Mycielski 1902: 16). Mieszkańcy, których liczba dla przykładu w roku 1833 wynosiła 551 (Słownik geograficzny... 1880-1914: 724), a w 1931 - 1483, zajmowali się przede wszystkim murarstwem, stolarstwem, brukarstwem i rolnictwem, nie byli więc zbyt zamożnymi obywatelami. Adam Tomaszewski zauważa: „Ludność jest od dawna zasiedziała, na co wskazują powtarzające się te same nazwiska, a słaby tylko odpływ i przypływ ludności polskiej nastąpił dopiero po wskrzeszeniu Państwa Polskiego..." (Tomaszewski 1930: 1). Istotnym jest także fakt, że Łopienno w czasach komisji kolonizacyjnej zachowało charakter patriotyczny i wyznaniowy. W prasie lokalnej pisano: „... za lat kilka Łopienno ze swym schludnym i miłym kościółkiem zostanie jako polska wysepka na morzu kolonizacyi” („Goniec Wielkopolski” 1985), a w późniejszym okresie: „W całej parafii Łopieńskiej nie przeszedł w tym samym czasie [kiedy sprzedawano ziemię komisji w pobliskich miejscowościach - K.K.Ł.] ani jeden kawałek ziemi z rąk chłopskich w ręce niemieckie, choć pokus nie brakowało” („Orędownik” 1904).

\footnotetext{
${ }^{4}$ Należy zauważyć, że Łopienno nie ma monografii. Na uwagę zasługują dwa opublikowane opracowania częściowe: wspomniana książka ks. Władysława Stryjakowskiego oraz pozycja Adama Tomaszewskiego (1930) oraz przygotowane do druku opracowanie W. Stryjakowski (b.d.w.), Kronika proboszcza $w$ Łopiennie 1866-1900..."

5 Rok 1252 - nazwa Łopienno pojawia się w Kodeksie Dyplomatycznym Wielkopolski pod numerem 303, (Hładyłowicz 1932: 109).

6 W 1887 r. mieszkańcy Łopienna, chcąc uniknąć zbyt wysokich obciążeń finansowych (m.in. składek na pensje i utrzymanie burmistrza, podatki), po rozmaitych sprzeczkach w gronie radnych miejskich, zwrócili się do rejencji królewskiej z prośbą o zmianę miasta Łopienna na wieś. Ważnym aspektem związanym z przyczyną zrzeczenia się praw miejskich jest fakt, iż rejencja królewska nie chciała zatwierdzić burmistrza - Polaka wybranego przez radnych miasta Łopienna, a wyznaczeni przez komisję tymczasowi burmistrzowie nie mówili po polsku. Dodać należy, że większość mieszkańców Łopienna była wyrobnikami, a niewielu było zamożniejszych obywateli. W 1888 r. sejm prowincjonalny uznał miasto Łopienno za odpowiednie do wymazania go z liczby miast („Orędownik” 1888, nr 233; „Wielkopolanin” 1888, nr 233).
} 
Ważnymi instytucjami na terenie Łopienna ${ }^{7}$ były: Kościół katolicki parafialny pod wezwaniem Wniebowzięcia Najświętszej Marii Panny ${ }^{8}$ i szkoła. Na przełomie XIX i XX w. w Łopiennie powstały także inne instytucje, m.in. poczta, Urząd Stanu Cywilnego, ochronka dla dzieci biednych (Mycielski 1902: 207) oraz działało wiele towarzystw i organizacji, m.in. Liga Katolicka, Straż Pożarna, Towarzystwo Czytelni Ludowych, Koło Śpiewacze im. św. Cecylii.

\section{Szkoła w Łopiennie - rys historyczny}

Początki szkoły w Łopiennie nie są dokładnie znane. Na podstawie opracowania ks. Władysława Stryjakowskiego można stwierdzić, że pierwsze wzmianki o szkole pojawiają się w $1608 \mathrm{r}$.

Ks. Wincenty de Seve podał, że przy kościele był osobny dom, do którego dzieci na naukę się zgromadzały, dyrektorem tej szkoły był Jan Kędzierski, którego sam pleban utrzymywał... (...) W 1780 nie było domu szkolnego, tylko dzieci uczęszczały na naukę do organisty i do ks. Wikariusza, u których czytać, pisać i katechizmu się uczyły (Stryjakowski 1887: 38).

Kiedy Łopienno przeszło pod władzę pruską, we wsi urządzono szkołę z jednym nauczycielem, później utworzono trzyklasową szkołę z trzema nauczycielami (Stryjakowski 1887: 38). „Budynek szkolny został wybudowany obok kościoła na gruncie plebańskim za zezwoleniem władzy duchownej w 1837 roku" (tamże: 38; Archiwum Archidiecezjalne w Gnieźnie). Na podstawie znanych dokumentów archiwalnych wiemy, że w 1914 r. „stara szkoła została zakupiona na dom dla księdza wikariusza i sług kościelnych z salką parafialną dla dzieci uczęszczających na naukę przygotowawczą do Sakramentów świętych" (Gierłowski 1914: 11-12). Nowy budynek (4 sale oraz mieszkania dla nauczycieli) został otwarty w 1909 r. ${ }^{9}$

\footnotetext{
7 Na obecne Łopienno składało się w XIX i na początku XX w. kilka części: Łopienno (dawne miasto), Łopiennica (wcześniejsza nazwa Friedrichsfelde), Julianowo i Probostwo Łopienno. Nazwa Friedrichsfelde została zmieniona na Łopiennica na podstawie rozporządzenia Dz.U. Ministerstwa Byłej Dzielnicy Pruskiej 1920.06.21, nr 32. Łopiennicę przyłączono do wsi Łopienno na podstawie rozporządzenia Rady Ministrów z dnia 7 lutego 1930 r. („Dziennik Bydgoski” 1930).

8 Budowę świątyni rozpoczęto przed 1670 r.; jej konsekracja nastąpiła w 1686 r. Fundatorem kościoła - wzniesionego wg projektu Jerzego Catenazziego - był ksiądz Adam Smuszewski, właściciel wsi, https://www.nid.pl/pl/Informacje_ogolne/Zabytki_w_Polsce/rejestr-zabytkow/zestawieniazabytkow-nieruchomych/stan\%20na\%2030.09.2018/WLK-rej.pdf O historii kościoła pisali: ks. Władysław Styjakowski, ks. Franciszek Januchowski.

${ }^{9}$ Jedynym źródłem potwierdzającym fakt otwarcia szkoły w nowym budynku w 1909 r. jest zapis ołówkiem na 1 stronie Kroniki Szkoły w Łopiennie.
} 
Publiczna szkoła w Łopiennie, działająca zgodnie z regulującymi normatywnymi przepisami ${ }^{10}$, w latach 1919-1927 r. miała 5 oddziałów (Kronika Szkoły: 108), a w latach 1928-1931 była placówką 4-klasową (z 4 nauczycielami), a od roku 1931 do 1939 była trzyklasową publiczną szkołą powszechną - przyczyną tej zmiany było zwolnienie nauczycielki Krystyny Niederlag (wyznania ewangelickiego) (tamże: 204). Liczba dzieci wahała się między 212 w roku 1919 (Archiwum Państwowe w Poznaniu a) a 215 (w tym 193 katolickich i 22 ewangelickich) 1 września 1938 r. (tamże: 232). W 1926 r., zgodnie z ustawą z 17 lutego 1922 r. w brzmieniu ustawy z 25 listopada 1925 (Dz. U. Rz. P. 126, poz. 898) nastąpiło przekazanie majątku katolickiej gminy szkolnej w Łopiennie na rzecz gminy terytorialnej w Łopiennie (Archiwum Państwowe w Poznaniu (c)).

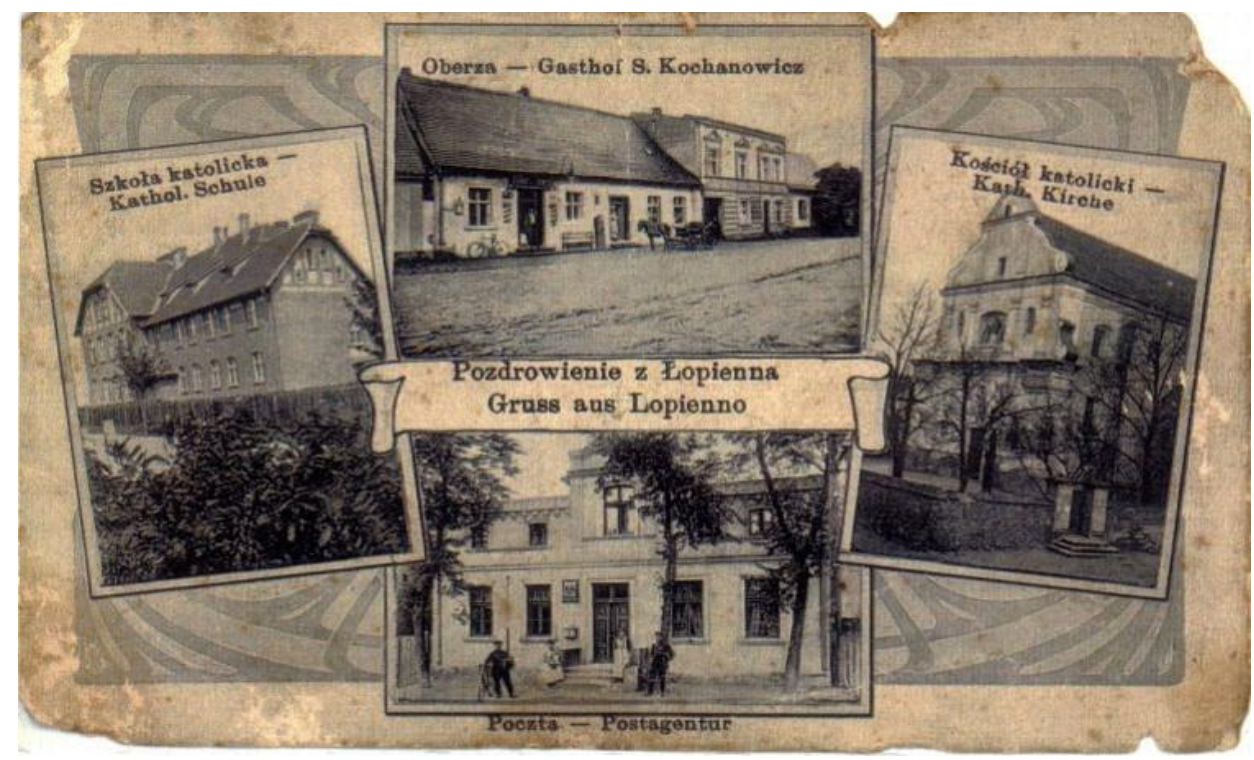

Fot. 1. Pocztówka z Łopienna, początek XX w.; w zbiorach Szkoły Podstawowej w Łopiennie

Oprócz szkoły katolickiej istniała w Łopiennie także szkoła ewangelicka. Pierwotna jej lokalizacja jest dość trudna do ustalenia. Prawdopodobnie budynek znajdował się w Łopiennie, po przeciwnej stronie kościoła, w połowie rynku (Archiwum Państwowe w Poznaniu (b)). Wiadomo również, że dom ten został kupiony od komisji kolonizacyjnej przez nauczyciela Karola Meissnera (tamże: 223), a po przeniesieniu szkoły ewangelickiej do dawnego dworu (1908) mieściła się tam agencja pocztowa. W latach 30 . XX w. dom został sprzedany Krystynie

\footnotetext{
10 Do najważniejszych zaliczyć należy: Ustawę z dnia 4 czerwca 1920 r. o tymczasowym ustroju władz szkolnych, Konstytucję Rzeczypospolitej Polskiej z marca 1921, Ustawę o zakładaniu i utrzymaniu publicznych szkół powszechnych z 1922 r. oraz Ustawę z dnia 11 marca 1932 r. o ustroju szkolnictwa.
} 
Kochanowicz i punkt pocztowy tam pozostał. Szkoła ewangelicka od 1908 r. została przeniesiona do budynku dawnego dworu (Strzałko 2013: 264-268; Archiwum Państwowe (b)), gdzie mieściły się dwie sale. Pierwsza przeznaczona dla 83 dzieci (26 małych, 24 średnich i 33 dużych), druga dla 71 dzieci (22 małych, 22 średnich i 27 dużych) ${ }^{11}$. W 1926 r., zgodnie z ustawą z 17 lutego 1922 r. w brzmieniu ustawy z 25 listopada 1925 (Dz. U. Rz. P. 126, poz. 898) majątek ewangelickiej szkoły w Łopiennicy przeszedł na własność gminy terytorialnej Łopiennicy (Archiwum Państwowe w Poznaniu (c)).

1 sierpnia 1927 r. „złączono szkoły w Łopiennicy [ewangelicka - K.K.Ł.] i Łopiennie [katolicka - K.K.Ł.] w jeden obwód szkolny pod nazwą: „Czteroklasowa Katolicka Szkoła w Łopiennie. Niemcy z Łopiennicy założyli protest przeciw temu złączeniu" (Kronika Szkoły: 176). Kuratorium przychyliło się do próśb niemieckich mieszkańców Łopiennicy i szkoły zostały rozdzielone (tamże: 177). Jednak 1 września 1928 r. zlikwidowano szkołę ewangelicką,

z powodu znacznego zmniejszenia się liczby dzieci niemieckich we wsi Łopiennica, zamknięto tamtejszą szkołę niemiecką, a dzieci przekazano do szkoły $w$ Łopiennie. Niemcy podnieśli z tego powodu alarm i zgłosili między innemi petycję do władz szkolnych z podpisami mieszkańców wsi, domagając się przywrócenia szkoły („Gazeta Wągrowiecka” 1928).

Na początku września ewangelickie dzieci strajkowały, dzięki czemu otrzymały osobną klasę z językiem niemieckim jako wykładowym i nauczycielem Ottonem Ehnke, jednak kolejne protesty rodziców nie przyniosły skutków (Kronika Szkoły: 181-182). Na początku września 1930 r. zlikwidowano klasę ewangelicką, a 40 dzieci przyłączono do klas katolickich. Budynek szkoły ewangelickiej został sprzedany w 1935 r. ss. Elżbietankom za cenę 11.000 zł z przeznaczeniem na ochronkę i przytułek (Archiwum Państwowe w Poznaniu (d)). Rada Gromadzka uchwaliła 26 maja 1935 r., że za zyskane ze sprzedaży budynku dawnej szkoły pieniądze zostanie zakupione gospodarstwo/ziemia mające zapewnić stały dochód przeznaczony na rzecz szkoły powszechnej w Łopiennie (tamże).

W interesującym nas okresie kierownikami szkoły (lub tymczasowymi kierownikami) byli: Mieczysław Ginter (1.07.1919-1.11.1919), Dionizy Michałowski (1.11.1919-31.03.1922), Edward Gruss (1.05.1922-1.11.1922), Zdanowska (1.11.1922-28.02.1923), Józef Mager (1.03.1923-15.11.1925), Stefan Iwicki (1.01.1927-3.09.1936) i Piotr Ławniczak (3.09.1936-1.09.1939) ${ }^{12}$.

\footnotetext{
11 Informacje na podstawie planów przebudowy budynku w 1908 r. (Archiwum Państwowe w Poznaniu (b)).

12 Kronika; o objęciu posady kierownika szkoły w Łopiennie przez p. Piotra Ławniczaka pisano także w lokalnej prasie („Gazeta Wągrowiecka” 1936).
} 


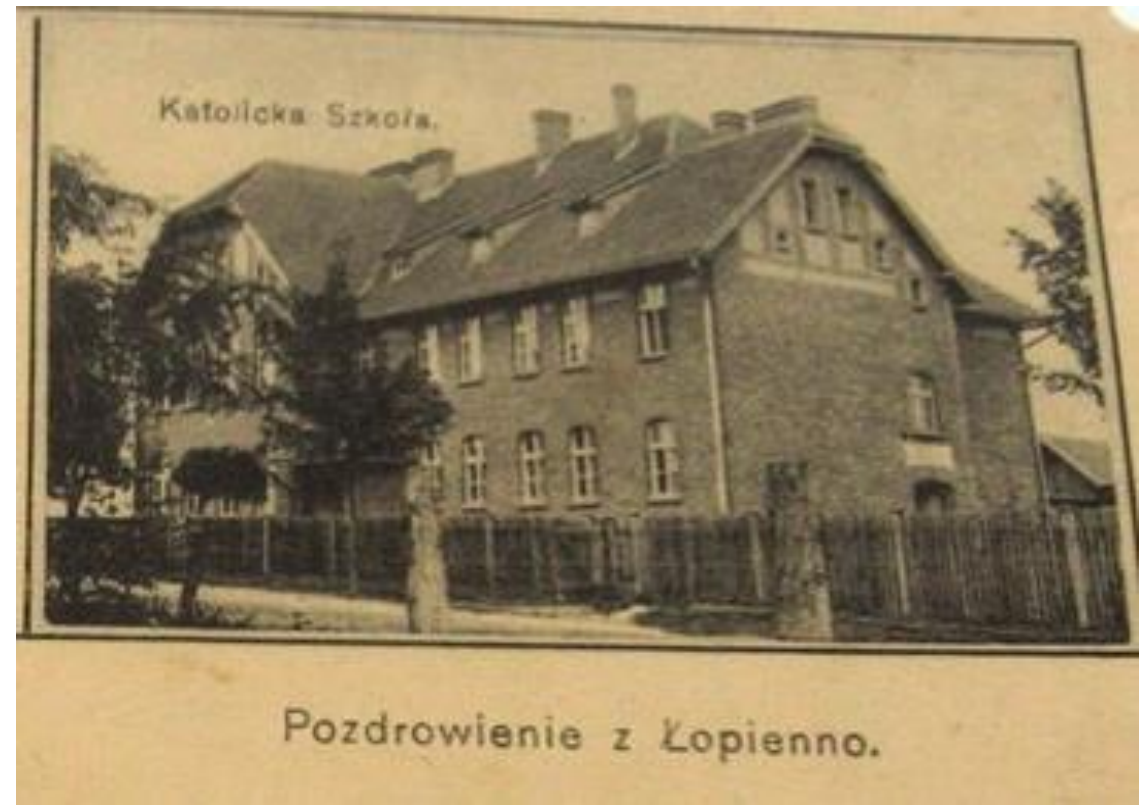

Fot. 2. Pocztówka z Łopienna (fragm.); w zbiorach Szkoły Podstawowej w Łopiennie

\section{Działalność Szkoły Powszechnej w Łopiennie na rzecz społeczności lokalnej}

\section{Obchody z okazji rocznic historycznych, wydarzeń politycznych, uroczystości religijnych}

Tradycja organizowania obchodów rocznic historycznych i upamiętniania wydarzeń politycznych była $\mathrm{w}$ Łopiennie $\mathrm{w}$ dwudziestoleciu międzywojennym bardzo żywa. Najbardziej doniośle obchodzono rocznice: uchwalenia Konstytucji 3 Maja, 11 listopada - odzyskania przez Polskę niepodległości, a także powstań: listopadowego i wielkopolskiego, czy 250-rocznicę wiktorii wiedeńskiej. Ponadto, rokrocznie świętowano imieniny Marszałka Józefa Piłsudskiego oraz prezydenta Rzeczypospolitej Polskiej Ignacego Mościckiego. Dodać należy, że dzieci uczestniczyły w obchodach uroczystości religijnych, m.in. św. Stanisława Kostki, procesji Bożego Ciała czy też przygotowywały jasełka. Warto podkreślić, że od 1928 r. organizowano obchody Dnia Dziecka.

Obchody uchwalenia Konstytucji 3 Maja były w Łopiennie w okresie międzywojennym bardzo ważną uroczystością, przygotowywaną rokrocznie. Istotne jest, że w ich organizację włączała się nie tylko szkoła (nauczyciele i dzieci), ale także wszystkie towarzystwa i organizacje lokalne. Niejednokrotnie powoływany był 
komitet organizacyjny, w skład którego zawsze wchodzili: sołtys, proboszcz, kierownik szkoły i wybrani obywatele. Wspólnotowy charakter miały wszystkie obchody, począwszy od 1920 r., kiedy w Kronice Szkolnej zapisano: „Szkoła dla siebie nic ozdobnego nie urządziła, lecz cała ludność, wszelkie warstwy społeczne, wszystkie towarzystwa, kółka, stowarzyszenia, bractwa i korporacje w jednej tylko uroczystości wspólnej brały udział" (Kronika Szkoły: 113).

Obchody uroczystości rocznicy uchwalenia Konstytucji 3 Maja w dwudziestoleciu międzywojennym organizowane w Łopiennie miały bardzo podobny przebieg. Najpierw uczestniczono we mszy świętej odprawianej w pobliskim parafialnym kościele. Następnie, na rynku odbywały się deklamacje i śpiewy patriotyczne oraz wykład okolicznościowy wygłoszony przez kierownika szkoły lub nauczyciela. W trakcie uroczystości była prowadzona zbiórka pieniężna - przeznaczana na lokalne inicjatywy, pomoc biednym dzieciom lub/oraz na Towarzystwo Czytelni Ludowych ${ }^{13}$, ale także na wsparcie dla dzieci śląskich czy też pomnik powstańca wielkopolskiego, Franciszka Adamczaka14. Podczas wielu obchodów wystawiano sztuki teatralne, w których grały nie tylko dzieci szkolne, ale także i mieszkańcy wsi ${ }^{15}$. Spotkanie kończył podniosły śpiew Roty. Wiele razy odbywała się także wiejska zabawa $^{16}$.

Fakt uroczystych obchodów tej rocznicy, bywał odnotowany w prasie regionalnej, co świadczyć może o kultywowaniu ważnych dla kraju wydarzeń historycznych, stających się przyczynkiem do wzbudzania patriotyzmu i lokalnej wspólnotowości. Za przykład niech posłuży fragment prasowej notatki z 1930 r.:

Po drodze przed szkołą w Łopiennie [orszak dzieci i stowarzyszeń z Gołaszewa przybył przed szkołę - K.K.Ł.] dołączają się ca 200 dzieci szkolnych łopieńskich i stowarzyszenia ze sztandarami, Kółko Rolnicze, Koło Śpiewackie, Stowarzyszenie Młodych Polek i Młodzieży Polskiej. Po nabożeństwie odbędzie się na rynku w Łopiennie uroczysta akademja, skaładająca

\footnotetext{
${ }^{13}$ Dla przykładu: w 1929 r. w Łopiennie na T.C.L. zebrano 60,00 zł z powiatu wągrowieckiego, była to kwota wysoka w porównaniu z innymi szkołami („Gazeta Wągrowiecka” 1929).

${ }^{14}$ Dla przykładu: „W roku 1928 zorganizowano z inicjatywy kierownika szkoły Iwickiego obchód rocznicy uchwalenia Konstytucji 3 Maja. Po zakończonym nabożeństwie, pochód przy dźwiękach muzyki udał się na rynek, gdzie pani prezes Młodych Polek, p. Donerówna wygłosiła odczyt o Konstytucji 3 Maja, a uczniowie i Towarzystwo Śpiewackie odśpiewało kilka pieśni, po których nastąpiły deklamacje dzieci szkolnych. Następnie pochód przeszedł na cmentarz, na grób powstańca Franciszka Adamczaka, gdzie Stefan Iwicki wygłosił odczyt na temat znaczenia powstania wielkopolskiego" (Kronika Szkoły: 179).

15 Np. podczas wieczernicy w roku 1924 wystawiono sztukę „X Pawilon” (Kronika Szkoły: 163-164).

16 Pierwsze obchody rocznicy uchwalenia Konstytucji 3 Maja odbyły się w Łopiennie w 1920 r. Uroczystość odbyła się 2 maja w sali pana Kiełczewskiego, a wstęp na nią kosztował 1 mk. Przykładowy program obchodów rocznicy uchwalenia Konstytucji 3 Maja z roku 1920: prolog (nauczycielka), śpiew Witaj majowa jutrzenko (Kółko śpiewackie), odczyt, deklamacje (Dzieci szkolne), śpiew Hej zawitała nam wiosenka, sztuka w 5 aktach pt. Walek Kosynier przygotowana przez nauczycielkę Fydównę wraz z mieszkańcami - amatorami, dziećmi szkolnymi i pozaszkolną młodzieżą, dalej śpiew W cichy wieczór, wystąpienie Michałowskiego [kierownik szkoły], a na koniec przemówienie ks. Gierłowskiego - proboszcza i odśpiewanie Roty (Kronika Szkoły: 113-114).
} 
się ze śpiewu dzieci szkolnych pod batutą nauczyciela p. Priebego z Piastowic, przemówienia nauczyciela p. Piątkowskiego z Gołaszewa oraz przysięgi Powstańców i Wojaków. Po odśpiewaniu Roty odbędzie się przy dźwiękach muzyki, pochód przez Łopienno do Stacji Sanitarnej, gdzie pierwsza część tej Łopieńskiej uroczystości zostanie zakończona („Gazeta Wągrowiecka" 1930a; Kronika Szkoły: 187).

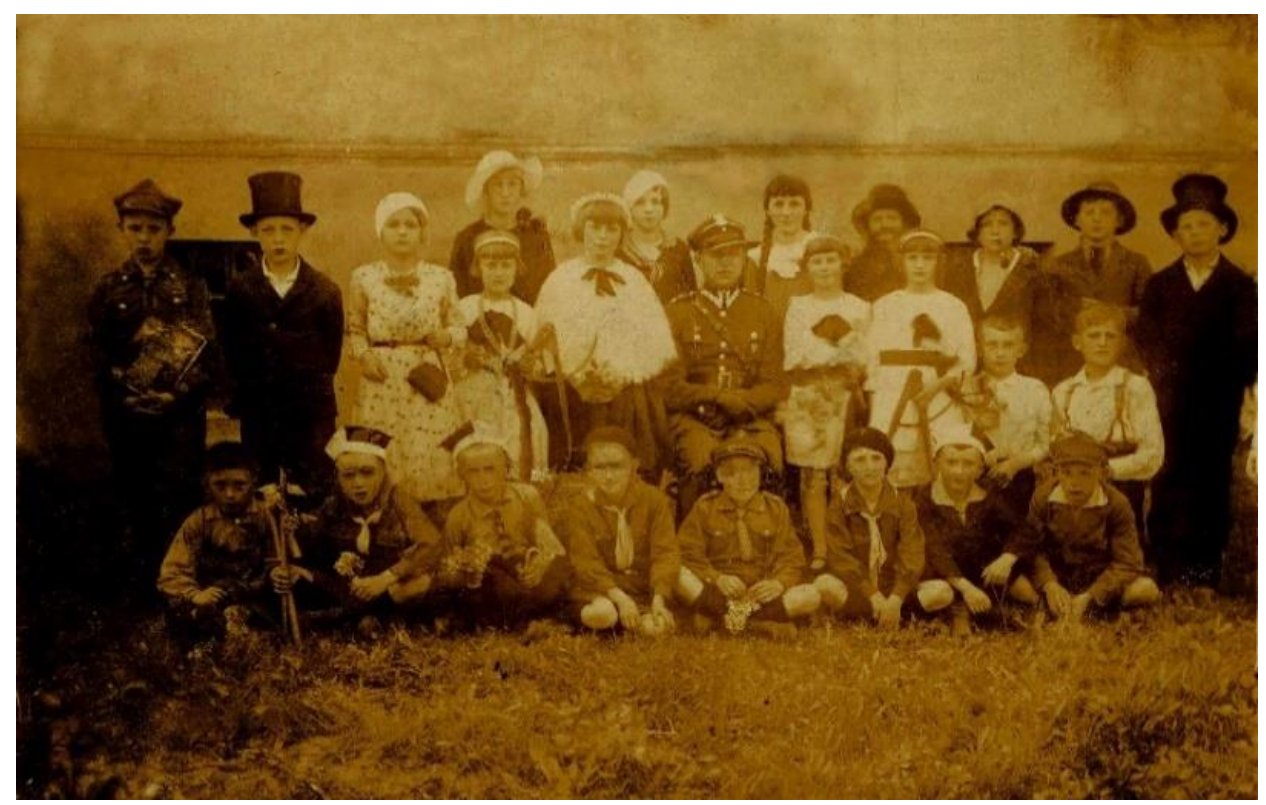

Fot. 3. „Niech się święci 3 maj” - lata 30-te XX w.; własność Lubomira Morawska

Co warte podkreślenia, uroczystości obchodów były przygotowywane bardzo pieczołowicie - dbano nie tylko o odpowiednio dobrane teksty i śpiewy - ich tytuły występują na kartach Kroniki - ale także o odpowiednią scenografię. Uczniowie byli w miarę możliwości poprzebierani w stroje nawiązujące do wydarzeń historycznych. Jako przykład niech posłuży fot. $3 \mathrm{z}$ początku lat 30 . XX w.

Tradycją działań prospołecznych nauczycieli i uczniów szkoły w Łopiennie było organizowanie obchodów rocznicy odzyskania przez Polskę niepodległości. Z okazji 10. rocznicy uczniowie i nauczyciele oraz mieszkańcy przygotowali dwudniową uroczystość. Pierwszego dnia, 10 listopada akademia była przeznaczona dla dzieci.

Rano, w poszczególnych klasach, odbywały się deklamacje i śpiewy okolicznościowe, następnie dzieci katolickie przeszły do kościoła parafialnego na nabożeństwo, gdzie ks. proboszcz Józef Gierłowski wygłosił specjalne kazanie. Wieczorem, około 120 dzieci brało udział w przedstawieniu „Oto 
dzień chwały" (w budynku dawnej szkoły ewangelickiej) odgrywanym przez hufiec Przygotowania Wojskowego i Wychowania Fizycznego. 11 listopada po uroczystym nabożeństwie, w którym uczestniczyły wszystkie towarzystwa oraz bardzo licznie zgromadzeni mieszkańcy (około 500 osób) ${ }^{17}$, na rynku wysłuchano patriotycznych pieśni w wykonaniu Koła Śpiewackiego im. św. Cecylii, następnie odbył się pochód przez wieś do parku, gdzie odśpiewano Rotę. Wieczorem odbyło się przedstawienie „Oto dzień chwały” dla mieszkańców oraz zabawa taneczna (Kronika Szkoły: 184-185).

Bardzo rozbudowane obchody, w które włączyły się wszystkie towarzystwa i organizacje działające w Łopiennie, odbyły się 11 listopada 1932 r. - został zawiązany także komitet organizacyjny, w skład którego oprócz przewodniczącego p. Cendlaka (wójt Mieściska) i sołtysa Łopienna p. Joppa wszedł także kierownik szkoły Stefan Iwicki oraz kilku mieszkańców Łopienna. Po nabożeństwie odprawionym przez ks. dziekana Gierłowskiego odbyła się defilada oddziałów Przygotowania Wojskowego i poszczególnych towarzystw (około 600 osób), a po niej akademia (w sali p. Rossy) z deklamacjami dzieci szkolnych i śpiewami okolicznościowymi (Towarzystwo Śpiewu) oraz referatem historycznym wygłoszonym przez nauczyciela Duszczaka. Na koniec, ks. Józef Gierłowski podziękował wszystkim za wspólną uroczystość. Po obiedzie żołnierskim odbyła się zabawa w sali p. Rossy (Kronika Szkoły: 206-207).

Także rocznice powstań narodowych i zwycięstw historycznych należały do ważnych tematów uroczystości lokalnych w Łopiennie. Bardzo uroczyście obchodzono pierwszy raz po odzyskaniu niepodległości rocznicę powstania listopadowego.

29 listopada [1919 roku] szkoła, raczej cały naród polski obchodził uroczyście rocznicę powstania listopadowego 1830 roku. Gremialnie zaprowadzono o 10 przed południem dzieci z szkoły do Kościoła, gdzie nabożeństwo tem więcej było uroczystem, gdyż zeszło się to święto narodowe z przez Konsystora Biskupi rozporządzonem nabożeństwem żałobnem za wszystkich poległych w wojnie światowej i przy wyswobodzeniu Polski. W szkole przewidziany był program bardzo uroczysty i złożony z trafnie i odpowiednio wybranych deklacyji i pieśni i śpiewów narodowych. Przemowę uroczystą wygłosił Michałowski [kierownik szkoły - K.K.Ł.], wykładając dzieciom fakty historyczne i wykazując znaczenie tego dnia dla całego narodu (tamże: 109-110).

Pamiętano również o rocznicy powstania wielkopolskiego. 28 grudnia $1924 \mathrm{r}$. uczniowie szkoły w Łopiennie przygotowali wraz z nauczycielami dla mieszkańców wsi wieczernicę z okazji rocznicy powstania wielkopolskiego. Jest to ważna uroczy-

\footnotetext{
${ }^{17}$ Liczba mieszkańców na początku lat 30. XX w. roku wynosiła około 1000.
} 
stość w Łopiennie, gdyż w 29.12.1918 na miejscowym dworcu kolejowym doszło do wygranej potyczki z Niemcami, co wpłynęło na pozytywny rezultat powstańczej walki o wyzwolenie Gniezna. Istotne jest również, że w trakcie obrony dworca zginął jeden z mieszkańców Franciszek Adamczak. Uroczyste obchody odbyły się w sali p. Kucharskiego, gdyż było tam więcej miejsca niż w salach szkolnych. Co intersujące, podczas tych obchodów jednoaktówki wystawili zarówno uczniowie szkoły, jak i nauczyciele, a całość „wypadła doskonale” (tamże: 166).

Do jednej z wielu propagowanych społecznie rocznic można zaliczyć obchody 250-lecia odsieczy wiedeńskiej. Mieszkańcy Łopienna po nabożeństwie żałobnym zostali zaproszeni na okolicznościową akademię, na którą składały się deklamacje dzieci i śpiewy Towarzystwa Śpiewackiego im. św. Cecylii.

Na kartach uroczystości przeznaczonych dla uczniów i mieszkańców Łopienna zapisały się obchody imienin marszałka Józefa Piłsudskiego i prezydenta RP Ignacego Mościckiego. Jako przykład niech posłużą obchody uroczystości imienin marszałka z 19 marca 1929 r.

Tego dnia w każdej klasie nauczyciel przygotował uroczystość upamiętniającą znaczenie i rolę Piłsudskiego. Następnie wszystkie dzieci katolickie wzięły udział w nabożeństwie, a później wróciły do domu, gdyż był to dzień wolny od nauk). Wieczorem odbyła się akademia ( $w$ budynku zlikwidowanej szkoły ewangelickiej) przygotowana przez uczniów dla mieszkańców (uczestniczyło w niej około 200 osób), a także wykład kierowania szkoły Stefana Iwickiego na temat życia i zasług Józefa Piłsudskiego. Na zakończenie odbył się pokaz sztucznych ogni (tamże: 185-186).

W 1936 r. dzień imienin marszałka Józefa Piłsudskiego miał szczególny charakter. Po nabożeństwie żałobnym, przy współudziale wszystkich łopieńskich towarzystw, przygotowano akademię wraz z przemówieniem nauczyciela p. Linkiewicza. W pierwszą rocznicę śmierci marszałka dzieci szkolne po zakończonym nabożeństwie przygotowały wraz z nauczycielami żałobną akademię w szkole (tamże: 220).

Po raz pierwszy obchody imienin prezydenta Rzeczypospolitej Polskiej Ignacego Mościckiego przygotowano w Łopiennie 1 lutego 1934 r. Po zakończonym nabożeństwie w pobliskim kościele uczniowie poszczególnych klas przedstawili akademię dla rodziców, Rady Szkolnej i Rady Gminnej (tamże: 212). Na przestrzeni lat można dostrzec, że zmieniał się charakter obchodów imienin prezydenta RP - zyskiwał charakter bardziej zamkniętych (szkolnych) spotkań. W 1936 r., „po nabożeństwie, w pięknie przystrojonych salach, z udziałem ks. proboszcza Zielińskiego, ks. wikarego Winczewskiego oraz członków Miejscowej Rady Szkolnej uczniowie przygotowali okolicznościowe deklamacje i śpiewy chóralne" (tamże: 218). 
(Poza)szkolne działania współbrzmiały również ze świętami, obchodami religijnymi, zaliczyć do nich można m.in. bożonarodzeniowe jasełka, uroczystość patrona młodzieży, św. Stanisława Kostki. Pierwsza wzmianka o uczestnictwie dzieci w uroczystości religijnej/kościelnej pochodzi z 1884 r., kiedy nauczyciele wraz z dziatwą szkolną uczestniczyli w obchodach jubileuszu 25-lecia kapłaństwa ówczesnego proboszcza łopieńskiej parafii ks. Władysława Stryjakowskiego (Stryjakowski 1866-1900).

W drugiej połowie grudnia 1920 r. Szkoła Powszechna w Łopiennie przygotowała i wystawiła jasełka. Interesujący jest fakt, iż odbyły się trzy inscenizacje bożonarodzeniowe: 19.12.1920 r. dla dzieci szkolnych, 26.12.1920 r. dla rodziców, a w trzecie święto dla wszystkich pozostałych mieszkańców wsi. Warto podkreślić, że na drugie i trzecie przedstawienie sprzedawano bilety, a dochód przeznaczono m.in. na ochronkę, Ligę Katolicką, na zeszyty dla biednych dzieci. Oprócz śpiewów kolęd oraz deklamacji dzieci szkolnych ważnym momentem każdego przedstawienia dla społeczności wiejskiej było przemówienie kierownika szkoły. Przygotowano również, podobnie jak w przypadku obchodów innych uroczystości, sztukę. Podczas ostatniego przedstawienia „wspomniano na bohaterskie powstanie grudniowe oraz wyswobodzenie Wielkopolski w r. 1918" (tamże: 131). Kierownik szkoły Dionizy Michałowski odnotował, że wszystkie przedstawienia ku zadowoleniu organizatorów (szkoły i organisty) udały się, tylko „na ostatnim część publiczności (młodzież pozaszkolna) nie umiała się zachować odpowiednie powadze rzeczy" (tamże).

19 listopada 1923 r. nauczyciele wraz z uczniami przygotowali wieczernicę ku czci św. Stanisława Kostki, na którą przybyli licznie mieszkańcy Łopienna. Uczniowie deklamowali i śpiewali pieśni okolicznościowe, a wykład na temat Nowe drogi życia młodzieży dzisiejszej wygłosił kierownik szkoły, Józef Mager. Także podczas tego spotkania zbierano dobrowolne datki, które przeznaczono na oprawę obrazów szkolnych (tamże: 159). W następnym roku dziatwa szkolna z okazji święta Stanisława Kostki, „przystąpiła wspólnie do Stołu Pańskiego w obecności całego grona nauczycielskiego" (tamże: 165).

W 1936 r. dzieci szkolne z nauczycielami wzięły czynny udział w procesji Bożego Ciała. Udekorowali budynek szkolny oraz przygotowali trzeci ołtarz, „Który pięknością i pomysłowością wzbudził ogólny podziw" (tamże: 219).

Ważnymi uroczystościami dla łopieńskiej społeczności były np. obchody związane z Dniem Dziecka. Pierwsza taka uroczystość odbyła się w szkole w dniach 1623 września 1928 r. pod hasłem „Tydzień Dziecka”. Obchody zapoczątkowało nabożeństwo i przemowa ks. proboszcza Józefa Gierłowskiego. Były także zabawy, wycieczki do lasu, nagrody itp. (tamże: 183) ${ }^{18}$. Innym przykładem jest Święto

\footnotetext{
${ }^{18}$ Interesujące jest, że uroczystości te obchodzono w Łopiennie zanim jeszcze odbyły się w Polsce oficjalne jego obchody; por.: „Międzynarodowy Dzień Dziecka ma swoje początki w 1925 roku. Wtedy to $w$ Genewie odbyła się Światowa Konferencja na Rzecz Dobra Dzieci. W Polsce natomiast Dzień Dziecka obchodzony był jeszcze przed II wojną światową. Pierwszy raz świętowano go bowiem już
} 
Dziecka, które urządzono dla uczniów szkolnych z Łopienna i Kłodzina 26 maja 1930 r. Wydarzenie to zostało odnotowane w lokalnej prasie:

Pochód składający się z ponad dwustu dzieci ustrojonych w chorągiewki i kwiaty wywarł imponujące wrażenie. W parku, w którym mieści się Stacja Sanitarna, odbywały się różne gry i zabawy. Liczne nagrody zakupione przez Rady szkolne, wręczali zwycięzcom, miejscowy kierownik szkoły p. Iwicki i nauczyciel p. Zamel z Kłodzina. Wieczorem o godzinie 9 zakończono tę piękną «majówkę» pieśnią «Wszystkie nasze dzienne sprawy» („Gazeta Wągrowiecka” 1930).

Także 1 czerwca 1931 r. obchodzono w łopieńskiej szkole Święto Dziecka zapoczątkowane nabożeństwem w kościele. Następnie dzieci przeszły do parku przy Stacji Sanitarnej, gdzie otrzymały smakołyki do jedzenia, odbyły się konkursy z nagrodami ufundowanymi przez Radę Szkolną Miejscową. Co ważne, w tym wydarzeniu brali także udział członkowie różnych łopieńskich towarzystw oraz rodzice dzieci szkolnych. Było to więc święto całej miejscowej społeczności (Kronika Szkoły: 199). W 1933 r. również upamiętniono Święto Dziecka nabożeństwem w pobliskim parafialnym kościele oraz całodzienną wycieczką do lasu, połączoną z grami i zabawami (tamże: 210).

Po raz pierwszy w roku 1933 zorganizowano w łopieńskiej szkole Dzień Matki, podczas którego po udziale w nabożeństwie i przemówieniu nauczycielki H. Nowakównej dzieci przedstawiły deklamacje i śpiewy wraz z Towarzystwem Śpiewu (tamże: 209).

Dzieci Szkoły Powszechnej w Łopiennie uczestniczyły w uroczystościach wynikających z rozporządzeń Ministerstwa Wyznań Religijnych i Oświecenia Publicznego. Przykładem może być przygotowanie obchodów „Dnia Francji” (4.05.1921) poświęconych braterstwu polsko-francuskiemu, podczas których zapoznano dzieci z relacjami między Polską a Francją oraz przybliżono postać Napoleona, a w $1923 \mathrm{r}$. obchodów ku czci rodaków w Ameryce (tamże: 156). Rozporządzenie Ministerstwa Wyznań Religijnych i Oświecenia Publicznego określiło, że luty 1927 r. będzie miesiącem książki. Uczniowie i nauczyciele przygotowali wieczernicę połączoną ze śpiewami, deklamacjami, teatrem i zabawą taneczną. W przygotowanie włączyli się także członkowie Towarzystwa Śpiewaków oraz panie ze Stowarzyszenia Młodych Polek. Dochód z tej uroczystości przeznaczono na zakup książek do biblioteki szkolnej (tamże: 173).

Dzieci uczęszczające do szkoły w Łopiennie angażowały się także w akcje wspierania zagranicznych rówieśników. Jako przykład niech posłuży zebranie

w 1929 roku, ale 22 września. Tego dnia dzieci po mszy w kościele szły na szkolne akademie, a później na wycieczki i zabawy. W tym dniu rozdawano również dzieciom słodycze. W 1952 roku święto zostało ustanowione na stałe" (https://wiadomosci.onet.pl/kraj/dzien-dziecka-data-zwyczajezyczenia/mm90117). 
843000 mk na fundusz „Dzieci polskie - dzieciom japońskim” (tamże: 158), a także wsparcie dla dzieci śląskich (tamże: 203).

Ważnym wydarzeniem (29.07.1928) w historii wsi był przyjazd do Łopienna prezydenta Ignacego Mościckiego, który został „owacyjnie powitany przez tutejszą ludność”. „Wręczył tutejszy sołtys p. Jopp Panu Prezydentowi chleb i sól, a Jolenta Sobecka, uczennica szóstego oddziału, wręczyła naręcz kwiatów" (tamże: 180). Następnie prezydent udał się do kościoła, skąd po odśpiewaniu Te Deum i Boże coś Polsce odjechał do Gniezna.

\section{Kursy dokształcające, wykłady i wystawy}

Nauczyciele szkoły w Łopiennie chętnie włączali się w dokształcanie społeczności lokalnej. W budynku szkolnym organizowano zarówno wykłady, wystawy, konferencje dla rodziców, pogadanki, jak i wieczorowe kursy.

W dniach 27-29 stycznia 1925 r. kierownik szkoły Józef Mager zorganizował wykłady dla Kółka Rolniczego parafii Łopienno, które odbywały się w godzinach popołudniowych. Prelegentami byli przedstawicie Szkoły Rolniczej w Janowcu: dyrektor Siuta i prof. Kozłowski. W wykładach uczestniczyło średnio około 29 osób (tamże: 167).

26 czerwca 1926 r. na terenie szkoły z okazji święta pieśni przygotowano również wystawę prac ręcznych, wśród których znalazły się 54 prace kobiece i 40 prac wykonanych z drzewa przez chłopców (tamże: 171-172).

W szkole w Łopiennie 28 stycznia 1928 r. zorganizowano pierwszą konferencję dla rodziców, podczas której omówiono zachowania uczniów i ich postępy w nauce oraz wygłoszono dwa referaty pt. $O$ alkoholizmie (przygotowała nauczycielka H. Rozdolska) i Zadanie matek (przedstawił kierownik szkoły Stefan Iwicki). „Frekwencja osób biorących udział w konferencjach wynosiła każdorazowo +/- 40” (tamże: 179). Konferencja o podobnej tematyce odbyła się rok później 20 kwietnia 1929 r. Nauczyciel Rozdolski wygłosił do rodziców uczniów klasy IV referat Alkohol i jego skutki dla zdrowia - obecnych było 15 rodziców (nie było żadnego rodzica dzieci niemieckich) (tamże: 186).

Na terenie szkoły we wrześniu 1930 r. kierownik Stefan Iwicki zorganizował także godzinne pogadanki dla mieszkańców na tematy: Obchód 25-lecia walki o szkołę polska, Dzieje i zagadnienia społeczności, Znaczenie zwycięskiego odparcia bolszewików pod wodzq Marszałka Józefa Piłsudskiego, W Stuletniq Rocznicę Powstania Listopadowego. Niestety, nie ma dokładniejszych informacji o przebiegu tych pogadanek, ani o liczbie uczestników (tamże: 194).

Stefan Iwicki wielokrotnie organizował także dokształcające kursy wieczorowe. W październiku 1930 r. brał udział w konferencji dla kierowników szkół w sprawie kursów wiejskich, na którą został zaproszony przez inspektora szkolnego Jankowskiego. Spotkanie to było efektem ogłoszenia okólnika z dnia 1 września 1930 w sprawie wieczorowych kursów Oświaty Pozaszkolnej, których celem było 
pogłębienie wiadomości, nabytych w szkole powszechnej, rozbudzenie w słuchaczach zainteresowań umysłowych i przysposobienie ich do dalszej pracy s a m o kształceniowej, podniesienie poziomu duchowego i kulturalnego słuchaczy oraz wychowanie świadomych, czynnych i odpowiedzialnych obywateli kraju (Dziennik Urzędowy 1930).

Od listopada 1930 r. do 15 marca 1931 dwa razy w tygodniu w godz. 18-20 odbywał się kurs dokształcający, na który zgłosiło się początkowo 20 kobiet w wieku 16-30 lat. W trakcie kursu ich liczba wzrosła do 44 osób. Uczestniczkami były przede wszystkim członkinie Stowarzyszenia Młodych Polek oraz Koła Śpiewackiego św. Cecylii w Łopiennie. Opał i światło opłacały biorące udział w kursie. Kurs odbywał się w formie wykładów i obejmował następujące przedmioty: gramatykę (odmienne i nieodmienne części mowy i składnia), rachunki (cztery działania na liczbach całkowitych pisemnie, obliczanie procentów), geografię (Polska współczesna), historię (od czasów legendarnych do czasów Zygmunta III). Największym zainteresowaniem cieszyły się rachunki i gramatyka (Archiwum Państwowe w Poznaniu (e)).

O wadze i znaczeniu organizowanych w Szkole Powszechnej w Łopiennie kursów dokształcających świadczyć może fakt, iż informacje o nich znalazły miejsce w prasie regionalnej. Za przykład niech posłuży wiadomość, że kierownik szkoły w Łopiennie Stefan Iwicki zorganizował „kursy wieczorne dokształcające dla młodzieży pozaszkolnej. Lekcje odbywają się w każdy wtorek i piątek od godziny 18-20” („Gazeta Wągrowiecka” 1934). Podobny kurs wieczorowy został zorganizowany od 12.11.1936 r. „Na kurs zapisało się 25 osób spośród młodzieży pozaszkolnej. Na kursie wykładają wszyscy nauczyciele tutejszej szkoły oraz miejscowe duchowieństwo" (Kronika Szkoły: 222). Od listopada 1937 do marca 1938 r. trwał kurs wieczorowy dla dorosłych. Zajęcia odbywały się w poniedziałki i czwartki w godz. 18-21. „Udział w kursie brało 17 młodzieńców w wieku 15-22 lat. Był to kurs II stopnia. Wykłady i zajęcia prowadzili wszyscy nauczyciele tutejszej szkoły" (tamże: 229).

\section{Rola nauczyciela w łopieńskiej społeczności}

Wszyscy kierownicy i pełniący obowiązki kierownika zaangażowani w działalność społeczną byli członkami wielu miejscowych organizacji. Jako przykład niech posłużą dwie postaci kierowników: Dionizy Michałowski i Stefan Iwicki. Pierwszy z nich był sekretarzem Ligi Katolickiej Parafialnej, bezpłatnie grał w niedzielę i święta na organach $\mathrm{w}$ kościele parafialnym, został zaprzysiężony w sądzie powiatowym na sędziego polubownego, a także na II zastępcę urzędnika stanu cywilnego. Ponadto pełnił funkcję zastępcy przewodniczącego sejmiku powiatowego (Kronika Szkoły: 129, 132, 139, 147). Także Stefan Iwicki był bardzo zaangażowany na rzecz pracy społecznej. Zajmował się krzewieniem idei oszczędności wśród ludności 
wiejskiej, był prezesem Koła BBWR, był dyrygentem Koła Śpiewackiego im. św. Cecylii (tamże: 206, 208; „Gazeta Wągrowiecka” 1934).

Jednak sytuacja nauczyciela w społeczności łopieńskiej nie była łatwa. „Jak każdy nauczyciel, [także i Józef Mager - K.K.Ł.] miał ciężkie przejścia z ludnością" (tamże: 169). Trudności wynikały z tego, że nauczyciele, kierownicy szkoły mieli stać na straży porządku i moralnego życia. Józef Mager sprzeciwił się, aby w sztuce, którą wystawiało Koło Śpiewackie, brały udział dzieci szkolne, gdyż była to sztuka dla nich nieodpowiednia, ponadto, próby odbywały się do późna w nocy, co negatywnie „demoralizująco” wpływało na dzieci. Dzieci za zgodą rodziców w sztuce grały, za co kierownik ukarał je aresztem szkolnym. Wywołało to otwarty konflikt kierownika z mieszkańcami, którzy nie tylko zgłosili skargę do ministerstwa, ale także utrudnili codzienne życie Magerowi. Kierownik, odchodząc ze swojego stanowiska, zapisał w kronice przestrogi dla następcy:

by był bardzo uważny z tutejszą ludnością i jeśli zacznie działać społecznie, [niech - K.K.Ł.] najpierw wybada teren (...) Każdy nauczyciel dostaje tu przezwiska od dzieci i ludności. (...) W szkole musi być nauczyciel energiczny ale niech nie zastosuje kary chłosty bo może narazić się na nieprzyjemności, że cała wieś wpadnie mu do szkoły (Kronika Szkoły: 169).

Pomimo lokalnego kolorytu nauczyciele (kierownicy) swoją postawą i zaangażowaniem w działalność wielu organizacji i towarzystw kreowali życie społeczno-kulturowe wsi. Należy również podkreślić stałą współpracę między nimi a miejscowym proboszczem oraz sołtysem wsi.

Szkoła ze swoją infrastrukturą wykorzystywana była również na rzecz pracy dla środowiska lokalnego. W jej murach odbywały się głosowania do sejmu i senatu (5.11.1922), obchody 25-lecia Koła Śpiewaczego św. Cecylii (14.08.1927).

\section{Zakończenie}

Szkoła Powszechna w Łopiennie w latach 1919-1939 oprócz podstawowych funkcji - edukacyjnej i opiekuńczo-wychowawczej - pełniła funkcję kulturotwórczą. Niewątpliwie to działalność nauczycieli, a szczególnie kierowników placówki (wraz z ks. proboszczem i sołtysem) wpłynęły na rozwój aktywności kulturowo-społecznej Łopienna. Owa aktywność (poza)szkolna wynikała zarówno z inicjatyw lokalnych wyżej wymienionych liderów, jak i z dyrektyw ministerialnych, przykładem których może być np. okólnik dotyczący organizacji kursów dokształcających dla młodzieży i osób dorosłych. Wszelkie przejawy działalności szkoły na rzecz społeczności były bardzo ważne, gdyż niejednokrotnie dla dorosłych mieszkańców Łopienna wzięcie udziału w obchodach uroczystości było jedynym spotkaniem z kulturą, możliwością zdobycia i pogłębienia wiedzy oraz tworzenia więzi małej ojczyzny. 
Istotne jest także szerokie poparcie społeczności łopieńskiej względem różnorodnych działań kulturowych. W uroczystościach okolicznościowych uczestniczyły nie tylko dzieci szkolne pod nadzorem nauczycieli, dla których już sam udział był lekcją patriotyzmu i miał wydźwięk wychowawczy, ale także sami dorośli, szczególnie ci, którzy należeli do działających licznie towarzystw i organizacji. Wystarczy przywołać współpracę kierowników szkoły z Kołem Śpiewaczym im. św. Cecylii, Stowarzyszeniem Młodych Polek itp. Można więc powiedzieć za Jerzym Topolskim, że

Nadal cechą charakterystyczną [Wielkopolski] był rosnący zasięg kultury, wyrażający się przede wszystkim w rozwoju szkolnictwa, oświaty i szerokiego, także amatorskiego ruchu kulturalnego (głównie muzycznego, chóralnego, częściowo teatralnego) (Topolski 2018: 295).

Owo (współ)działanie różnych organizacji na rzecz społeczności lokalnej w pełni odzwierciedla także opinię Stefanii Bojarskiej o Wielkopolsce: „Wszystkie stowarzyszenia prowadzą mniej lub więcej planowaną działalność oświatową, wszystkie starają się oddawać rzetelne usługi członkom i - wszystkie są zahaczone jedne o drugie, tworząc całość" (Bojarska 1917: 60).

Mieszkańcy Łopienna chętnie uczestniczyli w różnych szkolnych inicjatywach - religijnych i patriotycznych, zapewne dlatego, że brały w nich udział ich dzieci i wnuki, ale także z poczucia przynależności lokalnej. Wspólnotowość okazywali także podczas wieców politycznych, uroczystości pogrzebowych ważnych lokalnych osobowości, np. nauczyciela Michała Fischera, w pogrzebie którego uczestniczyli zarówno nauczyciele szkoły katolickiej, jak i ewangelickiej (Kronika Szkoły: 160) oraz licznie zgromadzeni mieszkańcy, którzy darzyli szacunkiem zmarłego. Podobna sytuacja miała miejsce podczas pogrzebu ks. Józefa Gierłowskiego, w uroczystościach żałobnych wzięli udział licznie zgromadzeni księża, mieszkańcy oraz dzieci z nauczycielami (tamże: 216).

Podsumowując, należy zauważyć, że szkoła w małej społeczności lokalnej jest niezastąpioną organizacją społeczno-kulturową. Wszelkie przejawy jej działalności na rzecz środowiska lokalnego wpłynęły nie tylko na podniesienie poziomu intelektualnego mieszkańców, ale już od najmłodszych lat szkolnych kształtowały w dzieciach poczucie tożsamości lokalnej. Szczególnie było to widoczne, co trzeba jeszcze raz uwydatnić, podczas przygotowania obchodów uroczystości przez wszystkie towarzystwa i organizacje łopieńskie. Interesujące jest także to, że właściwie wiele przejawów kulturotwórczej roli szkoły $\mathrm{w}$ Łopiennie z okresu dwudziestolecia międzywojennego można także odnaleźć we współczesnej działalności tej placówki. Jednoczy ona, jak robiła to przed stu laty, mieszkańców na obchodach odzyskania przez Polskę niepodległości, rocznicy powstania wielkopolskiego, podczas różnych okolicznościowych przedstawień. Pielęgnowaną tradycją są także wspólne obchody Dnia Dziecka - piknik rodzinny odbywa się dokładnie 
w tym samym miejscu, w którym był ponad sto lat temu i podobnie jak wówczas także i dziś bierze w nim udział cała społeczność lokalna. Ponadto, współczesna szkoła również organizuje różnego rodzaju kursy, m.in. komputerowe dla seniorów. Trzeba także podkreślić fakt zaangażowania współczesnych liderów społecznych, wśród których niewątpliwie ważne miejsce odgrywają nauczyciele i dyrektor szkoły, w różne aktywności społeczne. Podobnie jak przed stu laty także i dziś swoją postawą, chęcią działania, nowatorskimi pomysłami kreują współczesną małą ojczyznę.

\section{Bibliografia}

Archiwum Archidiecezjalne w Gnieźnie, Zespół Archiwum Kurii Metropolitarnej, Szkoła w Łopiennie (1862-1889), sygn. 7.

Archiwum Państwowe w Poznaniu (a), oddział w Gnieźnie, Zespół: Inspektorat Szkolny w Wągrowcu, Statystyka 1928r., sygn. 25.

Archiwum Państwowe w Poznaniu (b), oddział w Gnieźnie, Zespół Komisja Kolonizacyjna, Friedrichsfelde, sygn. 60050.

Archiwum Państwowe w Poznaniu (c), oddział w Gnieźnie; Inspektorat Szkolny w Wągrowcu, Spisy majątków szkolnych 1925-1927, sygn. 29.

Archiwum Państwowe w Poznaniu (d), oddział w Gnieźnie, Zespół Akta dotyczące maj. Szkolnego w Łopiennie 1935-1938, sygn. 42.

Archiwum Państwowe w Poznaniu (e), oddział Gniezno, Inspektorat Szkolny w Wągrowcu, Wiejskie Kursy dokształcające 1929-1932, sygn. 36.

Biernacka M. (1938) Oświata a społeczno-kulturowe przeobrażenia wsi w okresie międzywojennym, „Etnografia Polska”, t. XXVII, z. 1.

Bojarska S. (1917) Nasz dorobek kulturalny. Przewodnik dla osób pracujących społecznie przystępujących lud do pracy społecznej na wsi albo w mieście. 1. Wielkopolska, Warszawa, Wydawnictwo Księgarni Kroniki Rodzinnej.

„Dziennik Bydgoski” 1930, nr 106.

Garbowska W. (1976) Szkolnictwo powszechne w Polsce w latach 1932-1939, Wrocław-Warszawa-Kraków, Zakład Narodowy im. Ossolińskich, Wydawnictwo Polskiej Akademii Nauk.

„Gazeta Wągrowiecka” 1928, nr 116. 
„Gazeta Wągrowiecka” 1930a, nr 56.

„Gazeta Wągrowiecka” 1930b, nr 91.

„Gazeta Wągrowiecka” 1934a, nr 202.

„Gazeta Wągrowiecka” 1934a, nr 273.

„Gazeta Wągrowiecka” 1934c, nr 274.

„Gazeta Wągrowiecka” 1936, nr 206.

Gierłowski J., List adresowany do Konsystorza, Archiwum Archidiecezjalne, Zespół Archiwum Kurii Metropolitarnej, Szkoła w Łopiennie (1862-1889), sygn. 7, k. 11-12.

Głowacka-Sobiech E. (2008) Badania regionalne w historii wychowania - problemy metodologiczne, „Biuletyn Historii Wychowania”, nr 24, s. 7-12.

Gołdyn P. (2019) Źródła do dziejów szkolnictwa w Polsce w XX wieku. Sprawozdania szkolnej, protokoły rad pedagogicznych, kroniki szkolne, Poznań, Wydawnictwo Naukowe Uniwersytetu Adama Mickiewicza.

„Goniec Wielkopolski” 1985, nr 196.

Grzelczyk M. Szkolnictwo powszechne w Polsce w latach 1918-1939 (ze szczególnym uwzględnieniem Wielkopolski) - praca niepublikowana, znajduje się w zbiorach $\mathrm{Pu}-$ blicznej Biblioteki Pedagogicznej w Poznaniu, b.r.w.

Hładyłowicz K. J. (1932) Zmiany krajobrazu i rozwój osadnictwa w Wielkopolsce od XIV do XIX wieku z dodatkiem 2 map, Lwów, Wydawnictwo Kasa im. Rektora J. Mianowskiego.

Jamrożek W. (1985) Repolonizacja szkolnictwa w Wielkopolsce i na Pomorzu w latach 1918-1928, „Studia i Materiały do Dziejów Wielkopolski i Pomorza”, t. XVI, z. 1.

Jamrożek W. (1989) Funkcja społeczna nauczyciela szkoły powszechnej w środowisku wiejskim w opinii Ruchu Ludowego II Rzeczypospolitej, „Acta Universitatis Lodziensis. Folia Pedagogika et Psychologia", nr 24, s. 33-48.

Jamrożek W. (2015) Kongresy i zjazdy pedagogiczne w rozwoju polskiej myśli i praktyki edukacyjnej (do 1939 roku), Poznań, Wydawnictwo Naukowe Uniwersytetu Adama Mickiewicza.

Kościński K. (1909) Przewodnik po Poznaniu i Wielkim Księstwie Poznańskiem, Poznań, Nakładem i czcionkami Drukarni św. Wojciecha.

Kronika Szkoły $w$ Łopiennie, Archiwum Państwowe w Poznaniu, sygn. 53/875/ $0 / 57 / 223$. 
Michalski S. (1962) Szkolnictwo powszechne i zakłady kształcenia nauczycieli w Wielkopolsce $w$ okresie międzywojennym, Poznań, Wydawnictwo Naukowe Uniwersytetu Adama Mickiewicza.

Mokrzecki L., Żerko J. (1989) Regionalizm $w$ badaniach i nauczaniu historii wychowania, „Rozprawy z Dziejów Oświaty”, nr 32, s. 13-21.

Mycielski J. (1902) Księga adresowa wszystkich miejscowości w Wielkim Księstwie Poznańskim, Poznań, Wydawnictwo Księgarnia Polska W. Tempłowicza.

„Orędownik" 1888, nr 233.

„Orędownik" 1904, nr 6.

Rocznik Dziejów Społecznych i Gospodarczych F. Bujak, J. Rutkowski (red.) (1935), t. 4, Lwów, Wydawnictwo Kasa im. Rektora J. Mianowskiego.

Sieciński W. (2016) Administracja i organizacja szkolnictwa powszechnego i średniego w II Rzeczypospolitej, „Studia Administracyjne”, nr 8, s. 79-98.

Słownik geograficzny Królestwa Polskiego i innych krajów słowiańskich (1880-1914), F. Sulimierski, B. Chlebowski, W. Walewski (red.), Warszawa t. 5, nakład F. Sulimirskiego i W. Walewskiego.

Spaleniak W. (1994/1995) Prasa polska w Poznaniu w okresie zaborów (główne kierunki rozwoju) w: $Z$ dziejów prasy wielkopolskiej XIX-XX wieku, M. Kosman (red.), t. 1, Poznań, Polski Dom Wydawniczy „Ławica”.

Stryjakowski W. (1887) Wiadomości o Łopiennie i jego kościele na pamiq̨tkę dwóchsetnej rocznicy konsekracji kościoła, Poznań.

Stryjakowski W. (b.d.w.) Kronika proboszcza w Łopiennie 1866-1900; z komentarzami i uzupełnieniami ks. Franciszka Januchowskiego; praca niepublikowana, w zbiorach rodziny Kabacińskich.

Strzałko M. (2013) Majątki Wielkopolskie, t. IX/1, powiat gnieźnieński, Szreniawa, Wydawnictwo Muzeum Narodowe Rolnictwa i Przemysłu w Szreniawie.

Szczepaniak M., Tyrchan G. (2015) Codzienność lat 1914-1918 na Ziemi Gnieźnieńskiej w świetle kronik szkolnych, Gniezno, Drukarnia „Dozór”.

Tomaszewski A. (1930) Gwara Łopienna i okolicy w północnej Wielkopolsce, Kraków, Nakładem Polskiej Akademii Umiejętności.

Topolski J. (1977) Marksizm i historia, Warszawa, Państwowy Instytut Wydawniczy.

Topolski J. (1978) O pojęciu i funkcjach historycznych monografii regionalnych, „Komunikaty Mazursko-Warmińskie", nr 2, s. 171-178. 
Topolski J. (2018), Wielkopolska poprzez wieki, Poznań, Wydawnictwo Poznańskie.

Trzebiatowski K. (1970) Szkolnictwo powszechne w Polsce w latach 1918-1932, Wrocław-Warszawa-Kraków, Zakład Narodowy im. Ossolińskich, Wydawnictwo Polskiej Akademii Nauk.

„Wielkopolanin” 1888, nr 233.

Wróblewska U. (2017) Gromadzenie i ochrona źródeł szkolnych, „Biuletyn Historii Wychowania", nr 37, s. 37-52.

\section{Źródła internetowe}

Dziennik Urzędowy z dnia 1 września 1930 r. https://jbc.bj.uj.edu.pl/Content/ 394317/PDF/NDIGCZAS019528_67786646.pdf [dostęp: 24.11.2019].

http:// eprints.rclis.org/16418/1/kolasa_gazety_pol.pdf [dostęp: 16.04.2015].

https://szukajwarchiwach.pl/92/338/0/?q=inspektorat+szkolny+w\%C4\%85growie c+XARCHro:92\&wynik=9\&rpp=15\&page=1\#tabZespol [dostęp: 25.11.2019].

https://wiadomosci.onet.pl/kraj/dzien-dziecka-data-zwyczaje-zyczenia/mm90117 [dostęp: 24.11.2019].

https://www.nid.pl/pl/Informacje_ogolne/Zabytki_w_Polsce/rejestr-zabytkow/ zestawienia-zabytkow-nieruchomych/stan\%20na\%2030.09.2018/WLK-rej.pdf [dostęp: 14.11.2019].

Kolasa W. M., Jarowiecki J. (2015) Najważniejsze polskie gazety do wybuchu pierwszej wojny światowej $w$ kontekście zabezpieczenia ich dla potomnych (charakterystyka, badania, zasoby), http://eprints.rclis.org/16418/1/kolasa_gazety_pol.pdf 